DIW BERLIN

Discussion

Papers
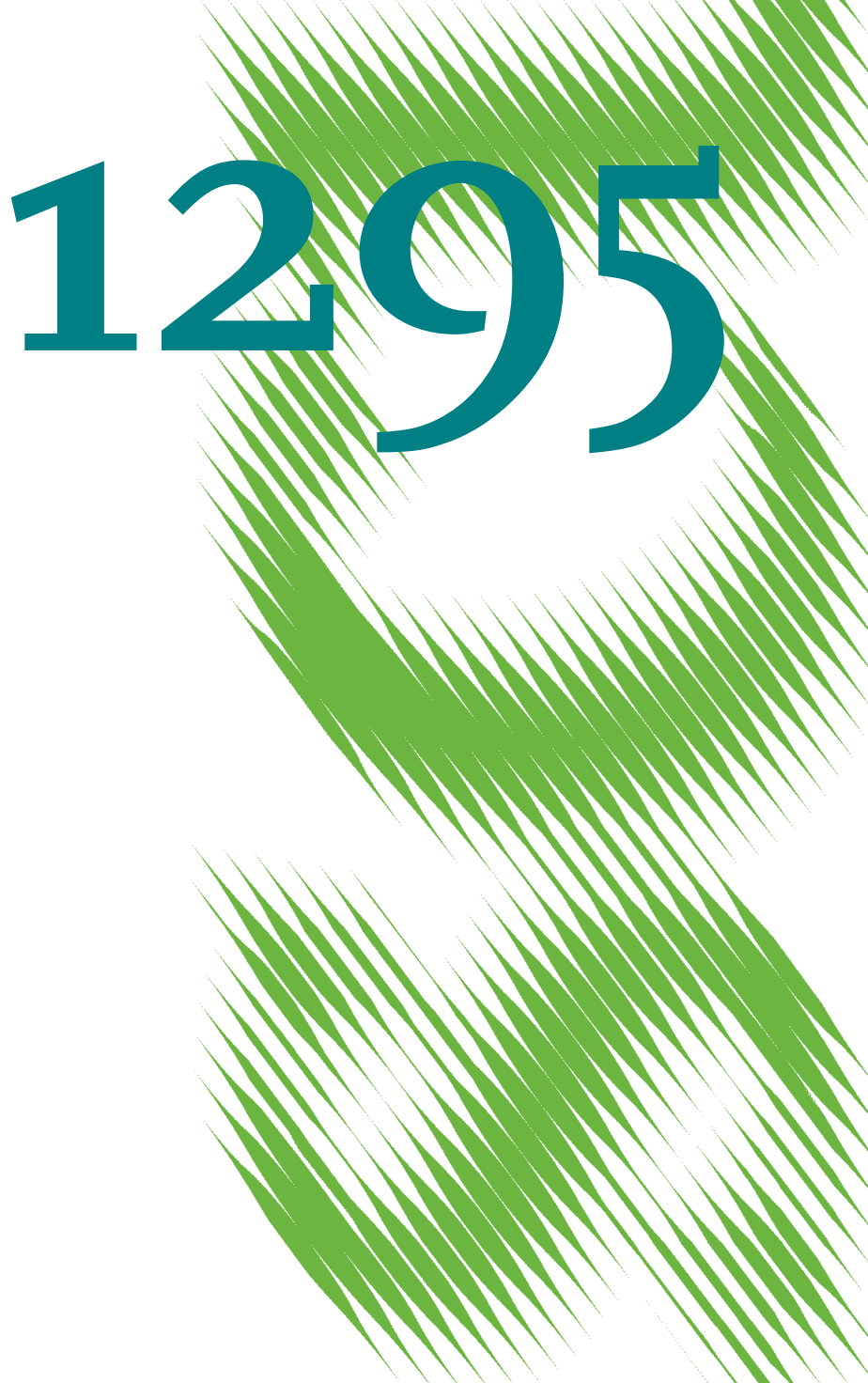

The European Debt Crisis and Fiscal Reaction Functions in

Europe 2000-2012 
Opinions expressed in this paper are those of the author(s) and do not necessarily reflect views of the institute.

IMPRESSUM

(C) DIW Berlin, 2013

DIW Berlin

German Institute for Economic Research

Mohrenstr. 58

10117 Berlin

Tel. $+49(30) 89789-0$

Fax +49 (30) $89789-200$

http://www.diw.de

ISSN print edition $1433-0210$

ISSN electronic edition 1619-4535

Papers can be downloaded free of charge from the DIW Berlin website:

http://www.diw.de/discussionpapers

Discussion Papers of DIW Berlin are indexed in RePEc and SSRN:

http://ideas.repec.org/s/diw/diwwpp.html

http://www.ssrn.com/link/DIW-Berlin-German-Inst-Econ-Res.html 


\title{
The European Debt Crisis and Fiscal Reaction Functions in Europe 2000-2012*
}

\author{
GUIDO BALDI \\ DIW Berlin, Germany \\ KARSTEN STAEHR ${ }^{* *}$ \\ Tallinn University of Technology, Estonia \\ Bank of Estonia, Estonia
}

20 May 2013

\begin{abstract}
After the global financial crisis, some governments in the EU experienced serious debt financing problems, while others were less affected. This paper seeks to shed light on the divergent fiscal performance by assessing the fiscal conduct in the EU countries before and after the outbreak of the crisis. Fiscal reaction functions of the primary balance are estimated for different groups of EU countries using quarterly data for the pre-crisis period 2001-2008 and for the post-crisis period 2009-2012. The pre-crisis estimations reveal some differences in persistence and cyclical reaction between different groups of countries, but generally little feedback from the debt stock to the primary balance. The countries that eventually developed fiscal problems do not stand out. The post-crisis estimations show less counter-cyclicality and much more feedback from the debt stock, and these reactions are particularly pronounced for the countries with severe fiscal problems.
\end{abstract}

JEL codes: E61, E62, H62, H63

Keywords: Fiscal reaction function, global financial crisis, debt crisis, structural break

\footnotetext{
* The authors would like to thank Davide Furceri, Jaanika Meriküll and Dmitry Kulikov as well as participants in the 2012 NBS conference "Fiscal policy and coordination in Europe" and an Eesti Pank seminar for useful comments. All remaining deficiencies are the responsibility of the authors. Staehr acknowledges support from Estonian Base Financing grant no. B617A and Estonian Target Financing grant no. SF0140059s12. The views expressed are those of the authors and not necessarily those of Eesti Pank.

* Corresponding author: Tallinn University of Technology, Akadeemia tee 3-486, 12618 Tallinn, Estonia. E-mail: karsten.staehr@ttu.ee.Tel.: +372 6204062. Mobile: +372 58161415.
} 


\section{Introduction}

Fiscal policy is a constant topic of debate in Europe, enshrined by the fiscal criteria of the Maastricht Treaty and the Stability and Growth Pact. The importance of fiscal performance has only been reinforced since the outbreak of the global financial crisis in the autumn of 2008 and, shortly thereafter, the European debt crisis. In the wake of these events, several governments in EU member states got problems borrowing from private capital markets. Interest rates on government debt shot up and, for some countries, debt markets dried up altogether. Meanwhile, other countries have seen interest rates on government debt drop to historically low levels as investors see them as safe havens. Nominal interest rates on long-term debt in the core countries have frequently been below two percent and short-term debt has occasionally been sold at negative interest rates. ${ }^{1}$

The radically different development between the EU countries is striking and constitutes the background for the European debt crisis. This paper aims at gaining further insights into the reasons for the diverging fiscal performance between the EU countries by comparing the fiscal performance in different groups of EU countries before and after the crisis. The paper contributes to the literature on the European debt crisis by assessing possible causes and consequences using fiscal reaction functions estimated on data for the 2000-2012 period. One issue of particular importance is whether diverging fiscal performances are related to different fiscal reactions to economic developments in the period before the global financial crisis. Another issue is whether the reactions of the fiscal stance have changed since the crisis.

Fiscal reaction functions are estimated for groups of EU countries based on quarterly data for the 2000-2012 period. The use of fiscal reaction functions is an increasingly important instrument to assess the fiscal policy stance. Until recently only annual fiscal variables were available. This necessitated the use of either very long time horizons with the risk of structural breaks or panel data with the risk of erroneous pooling. The advent of standardised quarterly data from Eurostat on fiscal variables makes it feasible to estimate reaction functions using data from the first quarter of 2000 and through the third quarter of 2012, but the short sample still necessitates that the countries are grouped or pooled. The dependent variable is the primary fiscal balance in percent of GDP and the explanatory variables include the lagged dependent variable, a proxy for the cyclical position, the accumulated debt stock, and also interest payments in some specifications. Such modelling of fiscal outcome bears a close resemblance to Taylor rules for monetary policy (Reicher 2012).

The time sample ranges from 2000:1 through 2012:3. This sample is chosen mainly due to data availability, but it also has some advantages. Although the outbreak of the global financial crisis is not situated in the middle of the sample, there are still a substantial number of observation points on either side of the event. This facilitates an analysis of a possible structural break around the outbreak of the crisis. At the same time, the short time sample implies that the likelihood of major structural breaks in the fiscal reaction functions other than the one pertaining to the financial crisis is limited. The years 2000-2012 comprise a period in which a large part of the institutional framework in Europe remained relatively stable and no major shocks besides the global financial crisis affected European economies.

Despite the relatively large number of observations that can be obtained from quarterly data, it is necessary to estimate reaction functions using groups or panels of countries. This makes

\footnotetext{
${ }^{1}$ The mood of the markets was succinctly conveyed in The Economist (2012, p. 25): "[I]t is the return of capital not the return on capital that matters".
} 
it possible to ascertain differences in the fiscal reaction among different groups of countries. The groups are formed based on two criteria. One division of the countries is based on their degree of integration into EU structures, while the other division is based on the severity of the fiscal and economic strain experienced by the countries after 2008.

The rest of the paper is organised as follows. Section 2 discusses the related literature and the gaps that this paper seeks to fill. Section 3 specifies the groups of EU countries and the data used in the estimations. Section 4 presents the results of the estimations for the pre-crisis period in which the fiscal reaction function includes only persistence and cyclical terms. Section 5 presents the main results for the pre-crisis period when measures of the debt stock and interest payments are included. Section 6 provides the results for fiscal reaction functions for the period after the outbreak of the global financial and the European debt crisis. Finally, Section 7 summarises the paper and discusses avenues of further research.

\section{Related literature}

The literature on fiscal reaction functions is largely empirical, but it is possible to rationalise different fiscal reaction functions as the outcome of a problem where policymakers minimise a loss function subject to constraints afforded by the economy, including the reaction of the private sector to different government policies (Gali \& Perotti 2001, Ballabriga \& MartiniezMongay 2003). The loss function may, for instance, comprise targets to the fiscal balance and short-term economic growth, but may also include a persistence component, arguably due to costs from rapid changes in fiscal variables. The end result is a specification according to which the fiscal variable of interest is a function of a persistence component, the cyclical position and possibly other factors.

In most empirical studies the explanatory variable is the realised fiscal outcomes, e.g. the overall realised primary budget balance, which is also the focus of this paper. Some studies seek to ascertain the policy intentions of policy-makers and to that end focus on fiscal variables that reflect policy decisions such as tax rates or discretionary spending categories (Ilzetzki \& Vegh 2008, Darvas 2010). Others use real-time data to provide a more realistic picture of fiscal policy-making (e.g. Bernoth et al. 2008).

Persistence of the fiscal stance may be due to a host of structural and political features, including information delays, policy-making constraints and implementation lags. A high degree of persistence may reflect that spending or taxation decisions are hard to change. In general, persistence seems to be greater in advanced economies than in developing and transition countries (Fatas \& Mihov 2001, 2008). For the euro area countries, Paloviita (2012) finds that persistence has been lower in the crisis countries in the periphery than in the rest of the euro area. The differences may be due to different structural and institutional features between the country groups. Afonso et al. (2010) find that persistence of fiscal policy is correlated with country income and the size of the government. This is in line with the findings of Friedman (2006) who, using quarterly data for the USA between 1959 and 2003, finds that the persistence in the fiscal balance as a ratio of GDP has increased over time.

For the cyclical reaction of fiscal policy, the same kind of differences between advanced and developing countries are often observed. Many empirical studies find that fiscal policy typically is counter-cyclical in developed economies, while it is pro-cyclical in emerging economies (Ilzetzki \& Vegh 2008, Afonso et al. 2008). Staehr (2008) shows that although fiscal 
balance is counter-cyclical in all parts of Europe, it is much more counter-cyclical in Western Europe than in the transition countries of Central and Eastern Europe.

Egert (2010) provides a detailed analysis of the cyclicality of the fiscal stance in the OECD member states and confirms that it is counter-cyclical in these countries. Sutherland et al. (2010) reach the same result but also find that the size of the counter-cyclical response of discretionary fiscal policy depends on the initial fiscal stance and debt level. Discretionary fiscal policy seems to be pro-cyclical in some countries and counter-cyclical in others, and it reacts to the cycle in a non-linear way, depending on the size of the debt stock.

By including the debt-to-GDP ratio in regression equations, one can test whether the budget balance reacts to the level of public debt. Bohn (1998) asserts that the reaction of the primary balance to the government debt stock can be seen as an indicator of the prudence or "sustainability" of the fiscal stance. If an increase in the debt stock is followed by a strengthening of the primary balance, fiscal policy can be seen as prudent or sustainable since more resources are made available to service the debt. Such estimations are evidently backward-looking and only uncover the feedback from the debt stock within the estimation sample, but they cannot predict the fiscal reaction of government in future and, hence, whether the government will pay its debt back. The methodology is widely used in the literature (see below) and a positive feedback from the debt stock to the primary balance is commonly used in general equilibrium models to ensure stability.

Bohn (1998) finds a positive and statistically significant coefficient for the USA in the 20th century and concludes that policy-makers eventually reacted to the accumulation of large debt positions over this period of time. Wyplosz (2006), Staehr (2008) and others implement the same methodology on European datasets and find some evidence of a positive feedback from the debt stock to the primary balance, but the feedback is often imprecisely estimated due to short data series. Piergallini \& Postigliola (2012) find that the primary balance in Italy has exhibited a positive reaction to the debt stock and argue that this suggests that politicians have taken corrective measures to ensure the sustainability of public finances in Italy. Estimating a fiscal reaction function for Brazil using monthly data, de Mello (2008) finds that the primary balance reacts positively and strongly to the lagged debt stock.

A number of studies examine how fiscal reaction functions change after a well-defined event that may affect the economic structure or the policy-making environment occurs. Bohn (1998) splits his century-long sample into subsamples and examines how the feedback from the lagged debt stock changes between the different subsamples. Several papers consider the fiscal reaction of the countries that sought to satisfy the fiscal criteria of the Maastricht Treaty in order to join the euro. Gali \& Perotti (2003) estimate fiscal reaction functions for eleven EMU countries over the 1980-2002 period and find that membership in the euro area did not cause discretionary fiscal policy to become less counter-cyclical when compared to the EU countries that did not seek to join the euro. Ballabriga \& Martiniez-Mongay (2003) find that fiscal policies changed little with the introduction of the euro.

Wyplosz (2006) decomposes the overall fiscal balance into the cyclically adjusted balance and a discretionary policy component defined as the overall balance minus the cyclically adjusted balance. The cyclically adjusted balance reacted more strongly to the business cycle before the countries entered the euro area than afterwards, while the discretionary component was pro-cyclical prior to entry, as countries sought to satisfy the criteria, but became acyclical afterwards. However, Marinheiro (2005) finds that the introduction of the euro rein- 
forced the counter-cyclicality of fiscal policy. Afonso et al. (2010) also find evidence of counter-cyclical reactions of fiscal policy in euro countries.

\section{Country groups and data}

The fiscal reaction functions are estimated for different groups of EU countries, since it is infeasible to estimate reaction functions for countries individually. The groups are formed based on two different criteria. The first criterion relates to the degree of EU integration, including the date when the country joined the EU. The second criterion is the severity of the public finance problems experienced after 2008.

The choice of panel data estimations on groups instead of individual countries hinges on three main concerns. First, the very short time sample in combination with rather "noisy" quarterly fiscal data makes it difficult to estimate fiscal reaction functions for individual countries as the coefficients are often imprecisely estimated. Second, the use of panels makes it possible to undertake estimations for the very short period after 2008:3, when the global financial crisis and the European debt crisis unfold. Third, estimation of 27 individual reaction functions would make it difficult to attain an overview of the obtained results, in particular since the standard errors in some cases will be rather large.

Table 1 shows the different groups used in the empirical analysis. The EU27 consists of all EU countries as of 2012. The countries are divided into groups based on two different criteria. One division of 25 or the 27 countries is based on their geographical location and degree of integration into EU structures. The group EA12 consists of the first 12 countries to join the euro area, all situated in Western Europe. The group DSU3 consists of the Denmark, Sweden and the UK, three countries from Western Europe, which remained outside the euro area. The group CEE10 is the group of 10 countries from Central and Eastern Europe that joined the EU in either 2004 or 2007.

Table 1: Groups of EU countries

\begin{tabular}{lll}
\hline EU27 & Explanation & Countries \\
\hline EA12 & $\begin{array}{l}\text { The first 12 euro area countries from } \\
\text { Western Europe }\end{array}$ & AE, DE, IE, GR, ES, FR, IT, LU, NL, AT, PT, FI \\
\hline DSU3 & $\begin{array}{l}\text { The } 3 \text { countries in the EU15 that are not } \\
\text { members of the euro area }\end{array}$ & DK, SE, UK \\
\hline CEE10 & $\begin{array}{l}\text { The } 10 \text { EU countries from Central and } \\
\text { Eastern Europe }\end{array}$ & BG, CZ, EE, LV, LT, HU, PL, RO, SI, SK \\
\hline EAnon7 & $\begin{array}{l}\text { The } 7 \text { countries from EA12 with limited } \\
\text { fiscal problems }\end{array}$ & BE, DE, FR, LU, NL, AT, FI \\
\hline EAcris5 & $\begin{array}{l}\text { The } 5 \text { countries from EA12 with substantial } \\
\text { fiscal problems }\end{array}$ & IE, GR, ES, IT, PT \\
\hline CEEnon7 & $\begin{array}{l}\text { The } 7 \text { countries from CEE10 with limited } \\
\text { fiscal problems }\end{array}$ & BG, EE, LT, CZ, PL, SI, SK \\
\hline CEEcris3 & $\begin{array}{l}\text { The } 3 \text { countries from CEE10 with substantial } \\
\text { fiscal problems }\end{array}$ & LV, HU, RO \\
\hline
\end{tabular}

Note: The country abbreviations are the official EU abbreviations; see also Table A.1 in Appendix A. 
The other division is based on the severity of the fiscal and economic problems experienced after 2008. The euro area countries in EA12 are divided into the groups EAnon7 and EAcris5. The group EAnon7 consists of the seven euro area countries in Northern Europe that have experienced relatively modest fiscal strain during the crisis, while the group EAcris5 consists of the five EA12 countries that are situated in the geographical periphery and have experienced substantial pressure after the global financial crisis (all, except Italy, receiving bailouts). The CEE10 countries from Central and Eastern Europe are divided into the groups CEEnon7 and CEEcris3. The group CEEnon7 consists of the seven Central European countries that managed the crisis without requiring a government bailout. The group CEEcris3 consists of Latvia, Hungary and Romania, i.e. the countries that faced serious fiscal problems and received bailouts in 2008 or 2009.

The dataset for the empirical analysis consists of quarterly data on public finances and output for each of the 27 EU countries. Data are from the Eurostat database. ${ }^{2}$ The variable BAL is the general government budget balance in percent of GDP (Eurostat classifier: gov_q_ggnfa). The variable INT is the general government interest payments in percent of GDP (classifier: gov_q_ggnfa). The primary budget balance PRIM is computed as the sum of the overall budget balance and the interest payments, i.e. PRIM = BAL + INT.

The variable DEBT is the general government gross debt stock as a per cent of GDP (classifier: gov_q_ggdebt). The numerator is a stock variable, while the denominator is a flow variable. The debt stock in percent of GDP is typically computed as the debt stock as a share of annual GDP. It is also a measure frequently referred to in EU agreements, including the Maastricht Treaty and the Fiscal Compact. To retain direct comparability between quarterly and annual measures of the debt stock in percent of GDP, Eurostat scales the quarterly GDP (by a factor of four) to attain an annualised GDP measure that is then used to compute the quarterly data series on debt in percent of GDP. This computation of the debt variable is important for the interpretation of the fiscal reaction functions estimated in Sections 5 and 6.

The dataset also comprises the variable G4Y, which is the percentage growth of GDP from the same quarter the previous year (classifier: namq_gdp_k). The variable is a straightforward measure of the cyclical stance.

The starting quarter of the data series is taken to be $2000: 1$, as the debt variable is only available from this quarter, and the last quarter is 2012:3. The budget balance BAL exhibits extreme values for Ireland for the period 2010:1-2011:3 and for Hungary for 2011:3; these data points have been omitted. Data on the budget balance and interest payments, and hence the primary balance PRIM, are not available for Germany and France for 2012:1-2012:3. Data on the debt stock is not available for Greece and Malta for 2000:1-2001:3. The GDP growth variable, G4Y, only starts in 2001:1 for Greece and Malta. Overall relatively few observations are missing, although the dataset is not a balanced panel.

Filtering and adjustment of data are kept to a minimum to facilitate replication and to ensure that results are not affected unduly by such measures. One consequence of this choice is that data are not seasonally adjusted, but instead comparisons are typically made to the same quarter the previous year. (Seasonally adjusted data for the budget variables are only available for 11 of the 27 EU countries.) Another important factor to note is the choice of GDP growth, G4Y, as the proxy of the business cycle stance. The construction of an output gap is fairly

\footnotetext{
${ }^{2}$ All data were downloaded on 1 February 2013 from the Eurostat database (http://epp.eurostat.ec.europa.eu/ portal/page/portal/statistics/search_database). The dataset is available from the authors upon request.
} 
complex and entails a number of decisions that are somewhat arbitrary. Egert (2010) shows that the results are usually rather similar when the GDP growth rate is used and when an output gap measure is used.

Table 2 shows the average values for the main variables for each of the eight country groups. (Corresponding statistics for the individual countries are provided in Table A.1 of Appendix A.) Data are shown for two time samples. The first sample is 2001:1-2008:2, where the end point corresponds to the last quarter before the bankruptcy of Lehman Brothers and the outbreak of the global financial crisis. The second time sample is 2009:1-2012:3, i.e. the period after the outbreak of the global financial crisis. Notice that the latter period does not include 2008:3 and 2008:4, as data are unusually volatile in these two quarters immediately after the bankruptcy of Lehman Brothers.

Table 2: Group-specific simple averages for the variables used in the analyses

\begin{tabular}{lcccccccc}
\hline & \multicolumn{2}{c}{ PRIM } & \multicolumn{2}{c}{ DEBT } & \multicolumn{2}{c}{ INT } & \multicolumn{2}{c}{ G4Y } \\
\hline & $\mathbf{2 0 0 1 : 1 -}$ & $\mathbf{2 0 0 9 : 1 -}$ & $\mathbf{2 0 0 1 : 1 -}$ & $\mathbf{2 0 0 9 : 1 -}$ & $\mathbf{2 0 0 1 : 1 -}$ & $\mathbf{2 0 0 9 : 1 -}$ & $\mathbf{2 0 0 1 : 1 -}$ & $\mathbf{2 0 0 9 : 1 -}$ \\
& $\mathbf{2 0 0 8 : 2}$ & $\mathbf{2 0 1 2 : 3}$ & $\mathbf{2 0 0 8 : 2}$ & $\mathbf{2 0 1 2 : 3}$ & $\mathbf{2 0 0 8 : 2}$ & $\mathbf{2 0 1 2 : 3}$ & $\mathbf{2 0 0 8 : 2}$ & $\mathbf{2 0 1 2 : 3}$ \\
\hline EU27 & 0.9 & -2.8 & 48.0 & 60.8 & 2.4 & 2.3 & 3.8 & -0.5 \\
\hline EA12 & 1.6 & -3.0 & 61.8 & 80.7 & 2.9 & 2.9 & 2.6 & -0.6 \\
\hline DSU3 & 2.7 & -1.9 & 43.9 & 52.8 & 2.2 & 1.9 & 2.5 & 0.1 \\
\hline CEE10 & -0.4 & -2.9 & 29.4 & 37.8 & 1.8 & 1.7 & 5.9 & -0.6 \\
\hline EAnon7 & 2.2 & -1.5 & 55.9 & 65.5 & 2.6 & 2.2 & 2.4 & 0.1 \\
\hline EAcris5 & 0.7 & -5.2 & 69.9 & 101.9 & 3.3 & 3.9 & 2.9 & -1.7 \\
\hline CEEnon7 & -0.1 & -3.1 & 28.8 & 32.7 & 1.6 & 1.4 & 5.8 & -0.1 \\
\hline CEEcris3 & -0.9 & -2.6 & 30.8 & 49.8 & 2.2 & 2.5 & 6.1 & -1.7 \\
\hline
\end{tabular}

Notes: The averages are simple averages for the countries in the group. PRIM, DEBT and INT are in percent of GDP, G4Y is the percentage change over the same quarter the year before.

Prior to the crisis, the average primary balance, PRIM, was positive for the EU27 group and for the Western European groups, but negative for the CEE groups. After the crisis the deterioration in the primary balance was substantial and the balance turned negative for all country groups. The smallest average primary deficits after the crisis were in the groups EAnon7 and DSU3, and the largest in the EAcris5 group, the group of euro area countries experiencing substantial fiscal problems.

The average government debt stock exhibits much variation between the country groups. Before the crisis the debt stock was much larger for the EA12 group than for the CEE group and this was particularly pronounced for the EAcris5 group of countries that later experienced fiscal problems. After the crisis a substantial increase of the debt stock is visible in most cases, in particular for the countries most affected by fiscal problems. The interest payments are generally relatively small. Interestingly, after the outbreak of the crisis the average interest payments fell in most country groups and remained essentially unchanged in groups of countries experiencing fiscal strain (EAcris5, CEEcris3). The latter finding suggests that the bailouts were successful in keeping interest payments down.

Finally, before the crisis the average rate of economic growth was much higher in the CEE countries than in the EA12 group, but within these groups there was little difference between the groups of countries that weathered the crisis well and those that experienced fiscal prob- 
lems. The rate of growth fell markedly in all country groups after the outbreak of the global financial crisis, but the decline was most pronounced in the CEE countries.

The time series properties of the variables are examined using a range of panel unit root tests, but the testing is rather complicated. First, the global financial crisis might have led to structural breaks the time series properties of the fiscal variables and the GDP growth series, and it is therefore reasonable to undertake the testing separately for the two samples of interest, i.e. 2001:1-2008:2 and 2009:1-2012:3. Second, the very short samples and the low power of most unit root tests may make it difficult to reject the null hypothesis of a unit root. Finally, the time series properties must be examined separately for each of the different groups of countries.

Due to space constraints, the tests are not reported here. The results are relatively consistent between the different country groups. The null hypothesis of a unit root can generally be rejected for the budget balance BAL, the primary budget balance PRIM, and the output growth G4Y. The exception is that G4Y may not be stationary for the period 2009:1-2012:3 for the two groups of countries with fiscal problems. The null hypothesis could not be rejected in the case of the gross debt stock DEBT, which is reasonable, given that it is a stock variable in large part aggregating BAL. The interest payment INT is a borderline case, both before and after the global financial crisis, in part reflecting that the debt stock on which the interests are paid has a unit root. It is evident that tests of time series properties should be interpreted with care when they are undertaken on datasets where the time dimension is very short as indeed is the case here. Nevertheless, the potential non-stationarity of the DEBT variable makes it important to evaluate the possibility of spurious correlation when the variable is included in fiscal reaction estimations.

\section{Fiscal reaction to business cycles}

We begin the empirical investigation with estimations of the fiscal reaction to the business cycle for each of the groups or panels in Table 1. Interest payments are largely the result of earlier decisions in the accumulation of debt and it is therefore appropriate to consider the reaction of the primary balance to various explanatory factors. The use of quarterly data entails a number of complications due to their seasonality and high noise-to-signal ratio. The following country specification was chosen:

PRIM $=$ Country dummy $+\beta_{1} \cdot \operatorname{PRIM}(-4)+\beta_{2} \cdot G 4 Y+\varepsilon$

The variables PRIM and G4Y are indexed by both country and time. (Four quarterly time dummies are also included but are not shown.) The country-specific dummy is included to control for time-invariant unobserved heterogeneity between the countries, $\beta_{1}$ and $\beta_{2}$ are the coefficients of interest and $\varepsilon$ is an error term.

The coefficient $\beta_{1}$ depicts the marginal effect of the primary budget balance lagged four quarters and is thus a measure of the persistence of the fiscal balance. The coefficient $\beta_{2}$ depicts the marginal effect of the rate of economic growth, G4Y, measured as percentage GDP growth over the same quarter the previous year. The specification in (1) explains the development of the fiscal stance over four quarters with the development of economic growth over the same period. Experimentation with different specifications of the estimations reveals that lagged values of G4Y generally have very little explanatory power. Likewise, if the estima- 
tions also include the primary budget balance lagged one, two and three quarters, the estimated coefficients of these lags are very small in numerical terms and never attain statistical significance.

Equation (1) can be rewritten to provide an interpretation more directly related to the fiscal policy implementation in most countries.

$\Delta_{4} \mathrm{PRIM}=$ Country dummy $+\left(\beta_{1}-1\right) \cdot \operatorname{PRIM}(-4)+\beta_{2} \cdot \mathrm{G} 4 \mathrm{Y}+\varepsilon$

The dependent variable $\Delta_{4} \mathrm{PRIM}$ is the change in the primary deficit from the same quarter the year before; $\Delta_{4} \mathrm{PRIM}$ is denominated in percentage points of GDP. All EU countries monitor their fiscal performance at the monthly and quarterly frequency and the outcome is typically compared with corresponding data from the year before. Equation (2) depicts how the primary balance changes over the year given the initial primary balance and the GDP growth during the year.

The specification in (1) and (2) is meant to account for data being quarterly and therefore with much noise and seasonality. The quarterly dummies will only "absorb” the seasonality insofar the seasonality affects the variables equally across the countries. We have experimented with the seasonally adjusted fiscal variables that are available for 11 countries. The main difference was that not only the seasonally adjusted primary balance lagged four quarters attain statistical significance, but also the variable lagged one, two and three quarters. The sum of the four lagged variables, however, was in all cases close to the estimate of $\beta_{1}$ in (1) and the estimate of $\beta_{2}$ did not change much. The upshot is that although all seasonality effects are not absorbed by the quarterly dummies, the qualitative results are broadly similar whether seasonally or non-seasonally adjusted data are used. The results presented below are based on data that are not seasonally adjusted.

The panel specification in (1) is estimated using two-stage instrumental variables estimation with country fixed effects. The fixed effect estimation methodology implies that the effects of the explanatory variables are identified via the time dimension. The method facilitates replication and is fairly robust to endogeneity of the debt stock (Celasun \& Kang 2006). The growth rate G4Y is approximately the sum of the quarterly GDP growth rates during the last four quarters, i.e. G4Y $\approx \mathrm{GY}+\mathrm{GY}(-1)+\mathrm{GY}(-2)+\mathrm{GY}(-3)$, where GY is the quarter-on-quarter growth rate. The lagged quarterly growth rates, GY(-1), GY(-2) and GY(-3), are determined before the primary balance PRIM, but PRIM could potentially affect GY. The explanatory variable G4Y is therefore instrumented using the lagged quarterly growth rates $G Y(-1)$, GY(-2) and GY(-3) as well as the variable G4YEU, which is the rate of GDP growth in the EU27 from the same quarter of the previous year. The specification is robust to other choices of instrument. Replacing G4YEU with the corresponding variable for the USA changes the results only marginally. Likewise, including lags of real energy prices as instruments does not change the results in qualitative terms.

Table 3 shows the results for each of the eight country groups. The column FE shows the average of the country fixed effects and in square brackets below their standard deviation. For the whole EU27, the estimated persistence coefficient is 0.666 and the coefficient of cyclical dependence is 0.250 . Both coefficients are estimated very precisely, in part due to the large number of observations. The large coefficient estimate of the lagged dependent variable implies a substantial degree of persistence. The degree of persistence, however, varies somewhat between the groups of EU countries. The fiscal balance exhibits a higher degree of persistence 
in the Western European groups than in the CEE groups, which is a result observed previously (Staehr 2008). The finding suggests a more flexible fiscal reaction in Central and Eastern Europe than in Western Europe.

Table 3: Fiscal reaction to business cycle, FE-IV estimation, 2001:1-2008:2

\begin{tabular}{|c|c|c|c|c|c|}
\hline & PRIM(-4) & G4Y & FE & $R^{2}$ & No. obs. \\
\hline EU27 & $\begin{array}{l}0.666^{* * *} \\
(0.038)\end{array}$ & $\begin{array}{l}0.250^{* * *} \\
(0.068)\end{array}$ & $\begin{array}{l}-0.89 \\
{[0.96]}\end{array}$ & 0.635 & 810 \\
\hline EA12 & $\begin{array}{l}0.682 * * * \\
(0.051)\end{array}$ & $\begin{array}{l}0.373^{* * *} \\
(0.099)\end{array}$ & $\begin{array}{l}-1.27 \\
{[0.86]}\end{array}$ & 0.679 & 360 \\
\hline DSU3 & $\begin{array}{l}0.656 * * * \\
(0.069) \\
\end{array}$ & $\begin{array}{l}0.651^{* * *} \\
(0.136)\end{array}$ & $\begin{array}{l}-0.65 \\
{[1.70]}\end{array}$ & 0.836 & 90 \\
\hline CEE10 & $\begin{array}{l}0.551^{* * *} \\
(0.075)\end{array}$ & $\begin{array}{c}0.061 \\
(0.084)\end{array}$ & $\begin{array}{l}-0.23 \\
{[0.79]}\end{array}$ & 0.594 & 300 \\
\hline EAnon7 & $\begin{array}{l}0.682 * * * \\
(0.073)\end{array}$ & $\begin{array}{l}0.404^{* * *} \\
(0.109)\end{array}$ & $\begin{array}{l}-1.11 \\
{[0.57]}\end{array}$ & 0.703 & 210 \\
\hline EAcris5 & $\begin{array}{l}0.662 * * * \\
(0.063)\end{array}$ & $\begin{array}{c}0.328^{*} \\
(0.186)\end{array}$ & $\begin{array}{l}-1.43 \\
{[0.97]}\end{array}$ & 0.609 & 150 \\
\hline CEEnon7 & $\begin{array}{l}0.621^{* * *} \\
(0.095)\end{array}$ & $\begin{array}{c}0.208^{* *} \\
(0.091)\end{array}$ & $\begin{array}{l}-0.91 \\
{[0.68]}\end{array}$ & 0.637 & 210 \\
\hline CEEcris3 & $\begin{array}{l}0.439 * * * \\
(0.119)\end{array}$ & $\begin{array}{l}-0.293 \\
(0.188)\end{array}$ & $\begin{array}{l}-1.50 \\
{[1.55]}\end{array}$ & 0.533 & 90 \\
\hline
\end{tabular}

Notes: The dependent variable is the primary budget balance, PRIM. Instrumental variable estimation with country fixed effects and quarterly dummies. The variable G4Y is instrumented using the following instruments: GY(-1), GY(-2), GY(-3), and G4YEU. Robust standard errors are shown in round brackets. Superscripts ***, **, * denote that the coefficient estimate is statistically different from 0 at the 1,5 and 10 percent level of significance, respectively. The column FE shows the average and, in square brackets, the standard deviation of the country fixed effects. Quarterly dummies are included but not reported.

The cyclical reaction also varies between the groups of EU countries. The primary balance is counter-cyclical in the groups consisting of Western European countries, while it is probably a-cyclical in the groups consisting of EU countries from Central and Eastern Europe. The cyclical reaction is particularly strong for the DSU3 group. Denmark and Sweden belong to this group together with the UK; and the fiscal balance of the Scandinavian countries has also in other studies been found to exhibit substantial sensitivity to the business cycle. Overall, the results regarding the cyclical reaction based on estimations using quarterly data correspond closely to results found using annual data (Egert 2010, in’t Veld et al. 2012).

Within the EA12 group there are only minor differences between the group of countries experiencing little strain (EAnon7) and the group eventually experiencing fiscal problems (EAcris5). Within the CEE countries, the cyclical reaction differs markedly between the two country groups. The fiscal reaction has been mildly countercyclical in the CEEnon7 group, while it appears to have been pro-cyclical or a-cyclical in the group of countries that experienced financing problems from 2008 onward. The three countries in the latter group experienced rapid economic growth in the sample period, but this does not appear to have led to a strengthening of the fiscal balance.

The average country fixed effect is negative in all country groups considered and it is noticeable that it varies little between the groups. The standard deviations of the country fixed effects 
are the largest for the groups with few countries, but overall the variation of the country fixed effects within each of the groups is relatively small.

The findings of this section can be summarised in a few points. First, the estimations of fiscal reaction functions using quarterly data provide results that are broadly in line with results in previous studies of fiscal reaction functions in Europe mainly using annual data. Second, the primary balance exhibits substantial persistence, although it varies somewhat between different country groups. Third, the primary balance in percent of GDP is highly counter-cyclical for the Western European groups, moderately counter-cyclical for the group of Central European countries and a- or pro-cyclical for the CEE countries that eventually received bailouts.

The results in Table 3 are attained using fixed effect estimations in which G4Y is instrumented. As explained earlier the results are not sensitive to the specific choice of instruments. Moreover, very similar are obtained if G4Y is not instrumented, see Table B.1 in Appendix B. Estimations using the overall balance, BAL, instead of the primary balance, PRIM, produce results that are very close to those presented in Table 3 (not shown). The results in Table 3 are also robust to a number of other specification changes, including shortening of the time sample at the beginning and the end of the sample. Likewise, removing a country from the different country groups does not generally affect the results in qualitative terms, although there are, as expected, some changes in coefficient estimates and standard errors.

\section{Fiscal reaction to debt and interest payments}

This section extends the analysis of fiscal reactions in the European Union by including terms that reflect the debt and interest obligations of the member countries. The analysis is carried out separately for the debt stock and the interest payments.

As discussed in Section 2, Bohn (1998) suggests examining the fiscal prudence or fiscal sustainability of a country (or group of countries), which entails the inclusion of the debt stock into a reaction function in which the dependent variable is the primary balance. Positive feedback from the debt stock to the primary balance implies that higher debt is followed by an improved primary balance, making more resources available for debt servicing.

Table 4 shows the results when the relative debt position lagged four quarters, DEBT(-4), is included in the fiscal reaction functions. The results for the fiscal persistence and the cyclical reaction are broadly the same as those presented in Table 3 and will not be discussed further. It is noticeable that the country fixed effects have larger standard deviations in the model with debt than in the model without, cf. Table 3; the levels of government debt vary markedly between the EU countries.

With all the EU27 countries in the panel, the coefficient of the debt variable is estimated to be 0.042. Bohn (1998) uses annual data from 1916 to 1995 for the USA and obtains a coefficient of 0.054 . The results are not directly comparable, however, since our results are based on estimations explaining the quarterly primary balance in percent of quarterly GDP by, among other variables, the debt stock in percent of GDP computed as the total debt stock divided by annualised GDP. The upshot is that the coefficient estimate of 0.042 attained for the full EU sample implies a much weaker short-term reaction of the primary balance to the debt stock 
than the result of Bohn (1998). ${ }^{3}$ Moreover, despite a large number of observations, the coefficient is imprecisely estimated and statistically significant only at the 10 percent level.

Table 4: Fiscal reaction to business cycle and debt, FE-IV estimation, 2001:1-2008:2

\begin{tabular}{|c|c|c|c|c|c|c|}
\hline & PRIM(-4) & G4Y & DEBT(-4) & FE & $R^{2}$ & No. obs. \\
\hline EU27 & $\begin{array}{l}0.678^{* * *} \\
(0.039)\end{array}$ & $\begin{array}{l}0.244^{* * *} \\
(0.065)\end{array}$ & $\begin{array}{c}0.042 * \\
(0.025)\end{array}$ & $\begin{array}{l}-2.99 \\
{[1.18]}\end{array}$ & 0.643 & 804 \\
\hline EA12 & $\begin{array}{l}0.682 * * * \\
(0.053)\end{array}$ & $\begin{array}{l}0.368 * * * \\
(0.100)\end{array}$ & $\begin{array}{c}0.030 \\
(0.025)\end{array}$ & $\begin{array}{l}-3.16 \\
{[1.18]} \\
\end{array}$ & 0.680 & 357 \\
\hline DSU3 & $\begin{array}{l}0.642^{* * *} \\
(0.072)\end{array}$ & $\begin{array}{l}0.612^{* * *} \\
(0.145)\end{array}$ & $\begin{array}{l}-0.028 \\
(0.030)\end{array}$ & $\begin{array}{c}0.79 \\
{[1.80]}\end{array}$ & 0.838 & 90 \\
\hline CEE10 & $\begin{array}{l}0.568 * * * \\
(0.077)\end{array}$ & $\begin{array}{c}0.086 \\
(0.078)\end{array}$ & $\begin{array}{c}0.032 \\
(0.041)\end{array}$ & $\begin{array}{l}-1.35 \\
{[0.98]}\end{array}$ & 0.597 & 300 \\
\hline EAnon7 & $\begin{array}{l}0.682^{* * *} \\
(0.073)\end{array}$ & $\begin{array}{l}0.404^{* * *} \\
(0.109)\end{array}$ & $\begin{array}{c}0.030 \\
(0.030)\end{array}$ & $\begin{array}{l}-2.81 \\
{[0.73]}\end{array}$ & 0.704 & 210 \\
\hline EAcris5 & $\begin{array}{l}0.663^{* * *} \\
(0.069)\end{array}$ & $\begin{array}{c}0.308 \\
(0.187)\end{array}$ & $\begin{array}{c}0.034 \\
(0.037)\end{array}$ & $\begin{array}{l}-3.78 \\
{[1.44]}\end{array}$ & 0.610 & 147 \\
\hline CEEnon7 & $\begin{array}{l}0.625^{* * *} \\
(0.100)\end{array}$ & $\begin{array}{l}0.223 * * * \\
(0.081) \\
\end{array}$ & $\begin{array}{c}0.017 \\
(0.044)\end{array}$ & $\begin{array}{l}-1.53 \\
{[0.64]} \\
\end{array}$ & 0.638 & 210 \\
\hline CEEcris3 & $\begin{array}{l}0.478 * * * \\
(0.114)\end{array}$ & $\begin{array}{l}-0.168 \\
(0.163)\end{array}$ & $\begin{array}{l}0.207 * * * \\
(0.066)\end{array}$ & $\begin{array}{l}-5.09 \\
{[6.40]}\end{array}$ & 0.572 & 90 \\
\hline
\end{tabular}

Notes: The dependent variable is the primary budget balance, PRIM. Instrumental variable estimation with country fixed effects and quarterly dummies. The variable G4Y is instrumented using the following instruments: GY(-1), GY(-2), GY(-3), and G4YEU. Robust standard errors are shown in round brackets. Superscripts ***, **, * denote that the coefficient estimate is statistically different from 0 at the 1,5 and 10 percent level of significance, respectively. The column FE shows the average and, in square brackets, the standard deviation of the country fixed effects. Quarterly dummies are included but not reported.

The weak or non-existent feedback from debt to the primary balance persists when the country groups are considered individually. The main exception is within the CEE countries, where there is a strong feedback for the group of CEE countries that eventually received bailouts. The estimated coefficient for the CEEcris3 group is very large and the short-term reaction from debt to the primary balance is comparable to the results in Bohn (1998). The result is robust to a number of specification changes and seems to hold for all three countries in the group. ${ }^{4}$ Within the pre-crisis sample period 2001:1-2008:2, the debt stock was stable in Latvia, increasing in Hungary and declining in Romania, so the positive feedback estimate has different implications for the overall development of the primary balance in the three countries.

The estimations in Table 4 use the dependent variable PRIM, which is stationary for all eight groups, while the explanatory variable DEBT may exhibit a unit root. This possible mismatch may lead to erroneous inference, an issue that we seek to address in a number of ways. First, a trend variable is introduced in all the estimations shown in Table 4, but the results are largely unchanged and are therefore not presented. Inclusion of time fixed effects (instead of the

\footnotetext{
${ }^{3}$ In the annual model of Bohn (1998) an increase of the debt stock by 1 percentage point would, ceteris paribus, increase the primary balance by 0.042 percentage points the following year. In our quarterly model a similar increase of the debt stock would increase the primary balance by $0.054 / 4=0.014$ percentage points the following quarter.

${ }^{4}$ When the equation is estimated for each of the three countries separately, the point estimates of the coefficient are, respectively, 0.178, 0.096 and 0.193 , but none of the estimated coefficients are statistically significant.
} 
quarterly dummies and the trend) has little impact on the coefficients of the lagged primary balance and reduced the size of the coefficients of the output growth variable somewhat, but it does not change the estimated coefficients of the lagged debt variable.

Second, we define a new variable, DDEBT, which is computed as the country-specific debt stock minus the average debt stock for the 27 EU countries. This variable depicts the debt position of the individual country relative to the EU27 average and the variable is borderline stationary in most cases. Table C. 1 in Appendix C shows the results when the lagged relative debt variable DDEBT(-4) is used instead of DEBT(-4) in the estimations. The coefficient estimates and the standard errors change somewhat, but the qualitative results are in line with those in Table 4.

The next step is to consider the impact of interest payments on the primary fiscal balance. Accumulation of debt entails interest payments and the idea is to examine to what extent e.g. higher interest payments are followed by a larger primary surplus and to what extent they are followed by a deterioration of the overall budget balance. The interest payments exhibit substantial variation over time and it is therefore expedient to compute a variable which depicts the average interest payments during the last year. This variable is labelled AINT and is defined as AINT $=(\operatorname{INT}+\operatorname{INT}(-1)+\operatorname{INT}(-2)+\operatorname{INT}(-3)) / 4$. Table 5 shows the results when the variable AINT is added to the basic specification in (1).

Table 5: Fiscal reaction to business cycle and interest payments, FE-IV estimation, 2001:12008:2

\begin{tabular}{|c|c|c|c|c|c|c|}
\hline & PRIM(-4) & G4Y & AINT & FE & $R^{2}$ & No. obs. \\
\hline EU27 & $\begin{array}{l}0.665^{* * *} \\
(0.038)\end{array}$ & $\begin{array}{l}0.260 * * * \\
(0.071)\end{array}$ & $\begin{array}{c}0.109 \\
(0.208)\end{array}$ & $\begin{array}{l}-1.20 \\
{[0.95]}\end{array}$ & 0.636 & 810 \\
\hline EA12 & $\begin{array}{l}0.680 * * * \\
(0.053)\end{array}$ & $\begin{array}{l}0.379 * * * \\
(0.103)\end{array}$ & $\begin{array}{c}0.045 \\
(0.247)\end{array}$ & $\begin{array}{l}-1.42 \\
{[0.86]}\end{array}$ & 0.679 & 360 \\
\hline DSU3 & $\begin{array}{l}0.649 * * * \\
(0.068)\end{array}$ & $\begin{array}{l}0.430 * * * \\
(0.166)\end{array}$ & $\begin{array}{l}-0.871^{* *} \\
(0.346)\end{array}$ & $\begin{array}{c}1.95 \\
{[1.75]}\end{array}$ & 0.854 & 90 \\
\hline CEE10 & $\begin{array}{l}0.563^{* * *} \\
(0.076)\end{array}$ & $\begin{array}{l}0.086 \\
(0.085)\end{array}$ & $\begin{array}{c}0.184 \\
(0.368)\end{array}$ & $\begin{array}{l}-0.72 \\
{[0.86]}\end{array}$ & 0.595 & 300 \\
\hline EAnon7 & $\begin{array}{l}0.667 * * * \\
(0.073)\end{array}$ & $\begin{array}{l}0.424^{* * *} \\
(0.117)\end{array}$ & $\begin{array}{c}0.192 \\
(0.356)\end{array}$ & $\begin{array}{l}-1.67 \\
{[0.47]}\end{array}$ & 0.703 & 210 \\
\hline EAcris5 & $\begin{array}{l}0.661 * * * \\
(0.071)\end{array}$ & $\begin{array}{l}0.326 * \\
(0.188)\end{array}$ & $\begin{array}{c}0.015 \\
(0.350)\end{array}$ & $\begin{array}{l}-1.50 \\
{[0.98]}\end{array}$ & 0.610 & 150 \\
\hline CEEnon7 & $\begin{array}{l}0.628^{* * *} \\
(0.100)\end{array}$ & $\begin{array}{l}0.253^{* * *} \\
(0.095)\end{array}$ & $\begin{array}{c}0.294 \\
(0.531)\end{array}$ & $\begin{array}{l}-1.66 \\
{[0.66]}\end{array}$ & 0.638 & 210 \\
\hline CEEcris3 & $\begin{array}{l}0.431^{* * *} \\
(0.119)\end{array}$ & $\begin{array}{l}-0.254 \\
(0.186)\end{array}$ & $\begin{array}{c}0.428 \\
(0.485)\end{array}$ & $\begin{array}{c}0.28 \\
{[2.25]}\end{array}$ & 0.538 & 90 \\
\hline
\end{tabular}

Notes: The dependent variable is the primary budget balance, PRIM. Instrumental variable estimation with country fixed effects and quarterly dummies. The variable G4Y is instrumented using the following instruments: GY(-1), GY(-2), GY(-3), and G4YEU. Robust standard errors are shown in round brackets. Superscripts ***, **, * denote that the coefficient estimate is statistically different from 0 at the 1,5 and 10 percent level of significance, respectively. The column FE shows the average and, in square brackets, the standard deviation of the country fixed effects. Quarterly dummies are included but not reported.

The coefficient of AINT does not attain statistical significance in most of the specifications. For the panel of all $27 \mathrm{EU}$ countries the coefficient is 0.109 with a standard error of 0.208 , which suggests that changes in the interest rate only affect the primary balance marginally and 
instead feed into changes in the overall balance. Similar results apply to the different groups except to the DSU3 group for which the estimated coefficient is negative and statistically significant. This finding is arguably the result of the small sample size but once again confirms that interest payments are not accompanied by corresponding changes in the primary balance.

Overall, the results for the interest payments in Table 5 are consistent with the results for the debt stock in Tables 4 and C.1. There seems to be only limited feedback from the debt stock or from average interest payments to the primary balance. The EU countries that eventually faced severe fiscal strain did not differ much in their fiscal reactions before the crisis. The conclusion from this analysis is, therefore, that it is not possible to link the pre-crisis fiscal reaction of different country groups to the subsequent performance after the outbreak of the global financial crisis.

\section{Fiscal reactions after the crisis}

The global financial crisis changed the conditions facing fiscal policy-making in numerous ways. Borrowing conditions tightened in some cases but eased in other cases and many EU countries faced economic downturns not seen for decades. Extraordinary spending occurred in some countries as governments bailed out banks and other firms. This section examines how these fundamental changes in the financial and economic conditions affected the fiscal reaction in the considered eight groups of countries. The idea is simply to re-estimate the reaction functions that include the lagged DEBT for the period after the outbreak of the global financial crisis. Table 6 shows results for the post-crisis sample 2009:1-2012:3 comparable to those the sample 2001:1-2008:2 in Table 4. The time sample is very short so the results should be interpreted with caution.

Table 6: Fiscal reaction to business cycle and debt, FE-IV estimation, 2009:1-2012:3

\begin{tabular}{|c|c|c|c|c|c|c|}
\hline & PRIM(-4) & G4Y & DEBT(-4) & FE & $R^{2}$ & No. obs. \\
\hline EU27 & $\begin{array}{l}0.569 * * * \\
(0.040)\end{array}$ & $\begin{array}{l}0.144^{* * *} \\
(0.055)\end{array}$ & $\begin{array}{l}0.191^{* * *} \\
(0.024)\end{array}$ & $\begin{array}{r}-11.70 \\
{[5.64]}\end{array}$ & 0.697 & 380 \\
\hline EA12 & $\begin{array}{l}0.719 * * * \\
(0.067)\end{array}$ & $\begin{array}{l}0.222 * * \\
(0.094)\end{array}$ & $\begin{array}{l}0.255^{* * *} \\
(0.037)\end{array}$ & $\begin{array}{r}-19.17 \\
{[7.26]}\end{array}$ & 0.767 & 157 \\
\hline DSU3 & $\begin{array}{l}0.537 * * * \\
(0.105)\end{array}$ & $\begin{array}{l}0.273^{* * *} \\
(0.084)\end{array}$ & $\begin{array}{l}0.139 * * * \\
(0.042)\end{array}$ & $\begin{array}{l}-7.52 \\
{[3.45]}\end{array}$ & 0.849 & 45 \\
\hline CEE10 & $\begin{array}{l}0.416 * * * \\
(0.065)\end{array}$ & $\begin{array}{l}0.153^{*} \\
(0.090) \\
\end{array}$ & $\begin{array}{l}0.138 * * * \\
(0.052)\end{array}$ & $\begin{array}{l}-6.44 \\
{[2.85]}\end{array}$ & 0.639 & 148 \\
\hline EAnon7 & $\begin{array}{l}0.824^{* * *} \\
(0.066)\end{array}$ & $\begin{array}{l}0.327 * * * \\
(0.099)\end{array}$ & $\begin{array}{l}0.215^{* * *} \\
(0.045)\end{array}$ & $\begin{array}{r}-14.04 \\
{[5.46]}\end{array}$ & 0.773 & 99 \\
\hline EAcris5 & $\begin{array}{l}0.414^{* * *} \\
(0.133)\end{array}$ & $\begin{array}{l}-0.006 \\
(0.183)\end{array}$ & $\begin{array}{l}0.242 * * * \\
(0.040)\end{array}$ & $\begin{array}{r}-23.61 \\
{[6.57]} \\
\end{array}$ & 0.756 & 58 \\
\hline CEEnon7 & $\begin{array}{l}0.402^{* * *} \\
(0.073)\end{array}$ & $\begin{array}{l}0.194^{* *} \\
(0.097)\end{array}$ & $\begin{array}{l}0.137 * * \\
(0.051)\end{array}$ & $\begin{array}{l}-6.27 \\
{[3.01]}\end{array}$ & 0.611 & 105 \\
\hline CEEcris3 & $\begin{array}{l}0.412^{* * *} \\
(0.169)\end{array}$ & $\begin{array}{l}-0.267 \\
(0.219)\end{array}$ & $\begin{array}{l}0.375^{* * *} \\
(0.135)\end{array}$ & $\begin{array}{r}-17.85 \\
{[9.66]}\end{array}$ & 0.715 & 43 \\
\hline
\end{tabular}

Notes: The dependent variable is the primary budget balance, PRIM. Instrumental variable estimation with country fixed effects and quarterly dummies. The variable G4Y is instrumented using the following instruments: GY(-1), GY(-2), GY(-3), and G4YEU. Robust standard errors are shown in round brackets. Superscripts ***, **, * denote that the coefficient estimate is statistically different from 0 at the 1,5 and 10 percent level of significance, respectively. The column FE shows the average and, in square brackets, the standard deviation of the country fixed effects. Quarterly dummies are included but not reported. 
For the full panel of $27 \mathrm{EU}$ countries, the persistence is slightly reduced and the cyclical reaction somewhat smaller for the post-crisis sample than for the pre-crisis sample, but the main difference is that the estimated coefficient of the debt variable is much larger than before and much more precisely estimated. The average of the time-invariant country fixed effects drops substantially and the variance of the fixed effects increase. The upshot is that, after the crisis, the EU27 countries attained a laxer discretionary fiscal stance reigned in by developments in the debt stock, while the persistence and the cyclical reaction changed little.

These results also hold for EA12 group. For the DSU3 group the cyclical reaction became more subdued, while it became marginally stronger for the CEE group. More interestingly, the feedback from the debt position became stronger in both the DSU3 and CEE groups although the effect is less strong than for the EA12 group.

There is some heterogeneity within the EA12. For the EAnon7 group of countries with limited fiscal problems, substantial persistence and counter-cyclicality are still present. For the EAcris5 group, the persistence drops markedly and the cyclical reaction is weak or nonexistent. Within the CEE10 group the main difference is that while the feedback from the debt stock for the CEEnon7 group is in line with the finding for the EAnon7 group, the feedback is very substantial for the CEEcris3 group while the average of the fixed effects in this group is very large in numerical terms.

The results point to a fundamental change in fiscal performance after the global financial crisis. The counter-cyclical response becomes weaker for the whole group of EU27 countries, but this result masks large heterogeneity as the fiscal stance generally changes little for the groups of countries experiencing few fiscal problems, while it becomes a-cyclical for the groups of countries with large fiscal problems. More importantly, after the crisis the primary balance reacts much more strongly to the accumulated debt stock in all country groups, but most pronouncedly for the two groups of countries with fiscal problems.

We subject the results in Table 6 to a number of robustness checks along the lines used in Section 5. First, when a trend variable is included in the estimations, all results remain essentially unchanged. Second, when the quarterly dummies are replaced by time fixed effects, the estimated persistence and debt feedback remain, while the estimated coefficient of G4Y becomes very small and statistically insignificant for all groups. The latter result reflects that the business cycles in the EU countries were very closely synchronised in the period after the global financial crisis and, consequently, the time fixed effects absorb the effect of the business cycle on the primary balance. Third, when the debt stock DEBT is replaced by the difference between the country-specific debt stock and the EU27 debt stock, the estimated feedback from the new debt variable is somewhat smaller in all cases, but the qualitative results, including the relative position between the country groups, remain unchanged. Finally, the results remain essentially unchanged, even when the post-crisis sample is shortened and taken to start in 2009:3 or 2010:1. This suggests that it is not specific events in the quarters immediately after the outbreak of the global financial crisis that drive the post-crisis results; the crisis appears to have altered fundamentally the fiscal reaction in the EU countries such that the primary balance reacts less to the business cycle but much more to the pre-existing debt stock. These changes in the fiscal reaction are present for all country groups, but are pronounced for the countries experiencing substantial fiscal strain. 


\section{Concluding comments}

This paper analyses fiscal performance in the European Union from 2000 until 2012, a period that includes the global financial crisis and the ensuing European debt crisis. The analyses are based on fiscal reaction functions estimated on quarterly data for, respectively, the pre-crisis period and the post-crisis period. The short time dimension of the data series necessitates the use of panel data estimation, but data are pooled into eight different, partly overlapping, panels or groups. The paper aims to address two main questions: First, are there differences in the fiscal reaction in the pre-crisis period that may explain why some countries developed severe debt financing problems while other countries were less severely affected? Second, how did the fiscal reaction functions change after the crisis?

The use of quarterly data for the estimation of fiscal reaction functions is relatively novel, but the initial analyses of a model with inertia and cyclical dependence of the primary balance show that the results conform with earlier studies based on annual data. For instance, the primary balance is more persistent and more counter-cyclical in the groups of countries from Western Europe than in the group of countries from Central and Eastern Europe.

The reaction of the primary balance to the accumulated debt stock is a means to assess fiscal sustainability, specifically whether the stance of the primary balance contributes to a stabilisation of the debt stock. Prior to the global financial crisis the feedback from the debt stock to the primary balance was modest and imprecisely estimated for almost all groups considered, with the exception of the group of three CEE countries that later developed fiscal problems. The lack of feedback from the accumulation of debt for most country groups is corroborated by analyses that show that the primary balance also reacts very little to interest payments.

Overall, the fiscal reactions before the global financial crisis differed little between the countries that escaped major fiscal problems and those that were less fortunate. There is, however, a striking difference between the countries with fiscal crisis in the euro area and in Central and Eastern Europe. In the latter group the primary deficit was largely a-cyclical but reacted to the accumulated debt stock, while in the former group the primary deficit was largely counter-cyclical and did not react to the debt stock. This suggests that fiscal crises took place on different backgrounds in the two regions as also witnessed by the different timing of the fiscal crises.

The fiscal reaction functions changed markedly after the outbreak of the global financial crisis. The main results are a substantial discretionary deterioration of the primary balance, less counter-cyclicality as well as a much larger and more precisely estimated feedback from the debt stock. These results apply for all country groups, but in particular for the countries experiencing fiscal problems. The global financial crisis constituted a structural break, after which the fiscal conduct differs fundamentally from the fiscal conduct before in the crisis in both qualitative and quantitative terms. The underlying reasons for these changes cannot be addressed within the present empirical framework.

The estimation of reaction functions provides additional insights into the very different fiscal performance of the EU countries after the global financial crisis. A number of arguably novel results are found, in part due to quarterly data facilitating estimations on short time sample. More research is needed to provide a better modelling of the dynamics of persistence and cyclical reaction in fiscal reaction functions estimated on quarterly data. Vector autoregressive 
models may be useful in this context. A main drawback of the use of quarterly is evidently the need to group the countries and undertake the estimations as panel data estimations. It remains an important, but challenging, area of future research to estimate fiscal reaction functions for individual countries using the available short time sample. 


\section{Literature}

Afonso, A., L. Agnello and D. Furceri (2010): "Fiscal policy responsiveness, persistence, and discretion”, Public Choice, vol. 145, no. 3, pp. 503-530.

Ballabriga, F. \& C. Martiniez-Mongay (2003): "Has EMU shifted monetary and fiscal policies”, in Buti, M. (ed.): Monetary and Fiscal Policies in EMU. Interactions and Coordination, Cambridge University Press, pp. 246-272.

Bernoth, K., A. H. Hallet \& J. Lewis (2008): "Did fiscal policy makers know what they were doing? Reassessing fiscal policy with real-time data”, DNB Working Papers, no. 169, Netherlands Central Bank.

Bohn, Henning (1998): “The behavior of U.S. public debt and deficits”, Quarterly Journal of Economics, vol. 113, no. 3, pp. 949-963.

Celasun, O. \& J. S. Kang (2006): “On the properties of various estimators for fiscal reaction functions”, IMF Working Paper, no. WP/06/182, International Monetary Fund.

Darvas, Z. (2010): “The impact of the crisis on budget policy in Central and Eastern Europe”, OECD Journal on Budgeting, vol. 2010/1.

de Mello, Luiz (2008): "Estimating a fiscal reaction function: the case of debt sustainability in Brazil”, Applied Economics, vol. 40, no. 3, pp. 271-284.

Egert, B. (2010): “Counter-cyclical economic policy”, OECD Economics Department Working Papers, no. 763, Organisation for Economic Co-operation and Development.

Fatas, A. \& I. Mihov (2001): "Fiscal policy and business cycles: an empirical investigation”, http://faculty.insead.edu/fatas/myc.pdf. (Published in Spanish in Moneda y Credito, vol. 118.)

Fatas, A. \& I. Mihov (2008): "Fiscal discipline, volatility and growth”, in T. Irwin, G. Perry, L. Serven \& R. Suescun (ed.): On Prudence or Abstinence: Fiscal Policy, Stabilization and Growth, World Bank.

Friedman, B. (2006): "Deficits and debt in the short and long run”, in: R. Kopcke, G. Tootell \& R. Triest (eds.): The Macroeconomics of Fiscal Policy, Cambridge MA: MIT Press.

Gali, J. \& R. Perotti (2003): “Fiscal policy and monetary integration in Europe”, Economic Policy, vol. 18, no. 37, pp. 533-572.

Ilzetzki, E. \& C. A. Vegh (2008): "Procyclical fiscal policy in developing countries: truth or fiction?”, NBER Working Paper, no. 14191, National Bureau of Economic Research.

in’t Veld, J., M. Larch \& M. Vandeweyer (2012): “Automatic fiscal stabilisers: what they are and what they do", European Economy - Economic Papers, no. 452.

Marinheiro, C. F. (2005): "Has the Stability and Growth Pact stabilised? Evidence from a panel of 12 European countries and some implications for the reform of the Pact", CESifo Working Paper Series, no. 1411, CESifo Group Munich.

Paloviita, M. (2012): "Real time uncertainty in fiscal planning and debt accumulation in the euro area”, Bank of Finland Research, Discussion Papers, no. 34/2012.

Piergallini, A. \& M. Postigliola (2012): "Fiscal policy and public debt dynamics in Italy, 1861-2009”, CEIS Research Paper, no. 248, Tor Vergata University, CEIS.

Reicher, C. Ph. (2012): “An estimated fiscal Taylor Rule for the postwar United States”, Economics Letters, vol. 114, no. 3, pp. 319-321. 
Staehr, K. (2008): "Fiscal policies and business cycles in an enlarged euro area”, Economic Systems, vol. 32, no. 1, pp. 46-69.

Sutherland, D., P. Hoeller, B. Egert \& O. Rohn (2010): “Counter-cyclical Economic Policy”, OECD Economics Department, Working Paper, no. 760.

The Economist (2012): “The bond market. To strive, to seek, to find, and not to yield”, The Economist, 28 June.

Wyplosz, C. (2006): “European Monetary Union: the dark sides of a major success”, Economic Policy, vol. 21, no. 46, pp. 207-261. 


\section{Appendix A: Country-specific summary statistics}

Table A.1: Country-specific averages for main variables used in analysis

\begin{tabular}{|c|c|c|c|c|c|c|c|c|c|}
\hline & & \multicolumn{2}{|c|}{ PRIM } & \multicolumn{2}{|c|}{ DEBT } & \multicolumn{2}{|c|}{ INT } & \multicolumn{2}{|c|}{ G4Y } \\
\hline & & $\begin{array}{c}\text { 2001:1- } \\
\text { 2008:2 }\end{array}$ & $\begin{array}{c}\text { 2009:1- } \\
\text { 2012:3 }\end{array}$ & $\begin{array}{c}\text { 2001:1- } \\
\text { 2008:2 }\end{array}$ & $\begin{array}{c}\text { 2009:1- } \\
\text { 2012:3 }\end{array}$ & $\begin{array}{c}\text { 2001:1- } \\
\text { 2008:2 }\end{array}$ & $\begin{array}{c}\text { 2009:1- } \\
\text { 2012:3 }\end{array}$ & $\begin{array}{c}\text { 2001:1- } \\
\text { 2008:2 }\end{array}$ & $\begin{array}{c}\text { 2009:1- } \\
\text { 2012:3 }\end{array}$ \\
\hline Belgium & $\mathrm{BE}$ & 4.2 & -1.1 & 98.3 & 98.5 & 4.9 & 3.6 & 2.0 & 0.4 \\
\hline Bulgaria & BG & 3.9 & -1.2 & 39.3 & 15.5 & 2.1 & 0.7 & 5.9 & -0.8 \\
\hline Czech Republic & $\mathrm{CZ}$ & -2.8 & -2.8 & 27.3 & 37.8 & 1.1 & 1.4 & 4.7 & -0.2 \\
\hline Denmark & $\mathrm{DK}$ & 5.1 & -0.9 & 42.7 & 43.6 & 2.4 & 1.8 & 1.6 & -0.9 \\
\hline Germany & $\mathrm{DE}$ & 0.3 & -0.1 & 64.6 & 77.8 & 2.9 & 2.6 & 1.5 & 0.8 \\
\hline Estonia & $\mathrm{EE}$ & 1.6 & -0.7 & 4.7 & 6.6 & 0.2 & 0.2 & 7.2 & -0.6 \\
\hline Ireland & IE & 1.6 & -8.6 & 30.2 & 88.2 & 1.2 & 2.9 & 4.8 & -1.1 \\
\hline Greece & GR & -1.0 & -5.9 & 103.5 & 143.5 & 5.4 & 6.0 & 4.1 & -3.6 \\
\hline Spain & $\mathrm{ES}$ & 2.6 & -7.5 & 46.6 & 61.5 & 2.1 & 2.2 & 3.3 & -1.2 \\
\hline France & FR & -0.1 & -4.2 & 63.4 & 83.0 & 2.8 & 2.5 & 1.7 & 0.1 \\
\hline Italy & IT & 1.8 & 0.4 & 107.6 & 119.8 & 5.2 & 4.7 & 1.2 & -1.2 \\
\hline Cyprus & $\mathrm{CY}$ & 1.1 & -3.0 & 65.6 & 67.1 & 3.3 & 2.6 & 3.7 & -0.4 \\
\hline Latvia & $\mathrm{LV}$ & -0.1 & -3.7 & 12.8 & 39.5 & 0.6 & 1.4 & 8.4 & -2.6 \\
\hline Lithuania & $\mathrm{LT}$ & -0.4 & -4.9 & 20.0 & 34.4 & 1.0 & 1.7 & 7.9 & -1.2 \\
\hline Luxembourg & $\mathrm{LU}$ & 2.2 & -0.4 & 6.3 & 18.3 & 0.2 & 0.4 & 4.1 & 0.2 \\
\hline Hungary & $\mathrm{HU}$ & -2.5 & 0.1 & 61.1 & 81.1 & 4.2 & 4.4 & 3.5 & -1.3 \\
\hline Malta & MT & -1.5 & -0.4 & 63.2 & 68.8 & 3.4 & 3.1 & 2.0 & 0.7 \\
\hline Netherlands & $\mathrm{NL}$ & 1.6 & -3.0 & 50.8 & 63.8 & 2.5 & 2.0 & 2.1 & -0.5 \\
\hline Austria & $\mathrm{AT}$ & 1.3 & -1.4 & 67.7 & 71.5 & 3.1 & 2.7 & 2.3 & 0.5 \\
\hline Poland & PL & -1.5 & -2.9 & 44.8 & 54.0 & 2.8 & 2.7 & 4.2 & 3.1 \\
\hline Portugal & PT & -1.4 & -4.2 & 61.7 & 96.2 & 2.8 & 3.5 & 1.1 & -1.3 \\
\hline Romania & $\mathrm{RO}$ & -0.2 & -4.3 & 18.6 & 28.7 & 1.7 & 1.7 & 6.3 & -1.4 \\
\hline Slovenia & SI & -0.3 & -4.0 & 26.7 & 40.2 & 1.7 & 1.7 & 4.5 & -2.0 \\
\hline Slovakia & SK & -1.4 & -5.0 & 38.9 & 40.3 & 2.4 & 1.5 & 6.3 & 1.2 \\
\hline Finland & FI & 6.0 & -0.2 & 40.3 & 45.7 & 1.9 & 1.4 & 3.2 & -0.6 \\
\hline Sweden & $\mathrm{SE}$ & 3.4 & 1.3 & 48.6 & 38.5 & 2.1 & 1.1 & 2.9 & 1.6 \\
\hline United Kingdom & UK & -0.4 & -6.1 & 40.4 & 76.5 & 2.1 & 2.7 & 2.9 & -0.3 \\
\hline
\end{tabular}

Notes: PRIM, DEBT and INT are expressed in percent of GDP, and G4Y is percentage change over the same quarter the year before. 


\section{Appendix B: OLS estimations}

Table B.1: Fiscal reaction to business cycle, OLS estimation, 2001:1-2008:2

\begin{tabular}{|c|c|c|c|c|c|}
\hline & PRIM(-4) & G4Y & FE & $R^{2}$ & No. obs. \\
\hline EU27 & $\begin{array}{l}0.667 * * * \\
(0.038)\end{array}$ & $\begin{array}{l}0.218^{* * *} \\
(0.056)\end{array}$ & $\begin{array}{l}-0.77 \\
{[0.92]}\end{array}$ & 0.636 & 810 \\
\hline EA12 & $\begin{array}{l}0.681^{* * *} \\
(0.051)\end{array}$ & $\begin{array}{l}0.308^{* * *} \\
(0.094)\end{array}$ & $\begin{array}{l}-1.10 \\
{[0.82]}\end{array}$ & 0.680 & 360 \\
\hline DSU3 & $\begin{array}{l}0.649 * * * \\
(0.068)\end{array}$ & $\begin{array}{l}0.528 * * * \\
(0.102) \\
\end{array}$ & $\begin{array}{l}-0.33 \\
{[1.63]}\end{array}$ & 0.837 & 90 \\
\hline CEE10 & $\begin{array}{l}0.559 * * * \\
(0.075)\end{array}$ & $\begin{array}{c}0.085 \\
(0.074)\end{array}$ & $\begin{array}{l}-0.37 \\
{[0.78]}\end{array}$ & 0.594 & 300 \\
\hline EAnon7 & $\begin{array}{l}0.674 * * * \\
(0.072) \\
\end{array}$ & $\begin{array}{l}0.259 * * \\
(0.104)\end{array}$ & $\begin{array}{l}-0.75 \\
{[0.58]}\end{array}$ & 0.706 & 210 \\
\hline EAcris5 & $\begin{array}{l}0.659 * * * \\
(0.064)\end{array}$ & $\begin{array}{l}0.373^{* *} \\
(0.165)\end{array}$ & $\begin{array}{l}-1.59 \\
{[1.04]}\end{array}$ & 0.610 & 150 \\
\hline CEEnon7 & $\begin{array}{l}0.621^{* * *} \\
(0.095)\end{array}$ & $\begin{array}{l}0.210^{* *} \\
(0.090)\end{array}$ & $\begin{array}{l}-0.92 \\
{[0.68]}\end{array}$ & 0.637 & 210 \\
\hline CEEcris3 & $\begin{array}{l}0.435 * * * \\
(0.120)\end{array}$ & $\begin{array}{l}-0.241 \\
(0.151)\end{array}$ & $\begin{array}{l}-1.18 \\
{[1.42]}\end{array}$ & 0.534 & 90 \\
\hline
\end{tabular}

Notes: The dependent variable is the primary budget balance, PRIM. Instrumental variable estimation with country fixed effects and quarterly dummies. The variable G4Y is instrumented using the following instruments: GY(-1), GY(-2), GY(-3), and G4YEU. Robust standard errors are shown in round brackets. Superscripts ***, **, * denote that the coefficient estimate is statistically different from 0 at the 1,5 and 10 percent level of significance, respectively. The column FE shows the average and, in square brackets, the standard deviation of the country fixed effects. Quarterly dummies are included but not reported. 


\section{Appendix C: Estimations with relative debt variable}

Table C.1: Fiscal reaction to business cycle and relative debt, FE-IV estimation, 2001:12008:2

\begin{tabular}{|c|c|c|c|c|c|c|}
\hline & PRIM(-4) & G4Y & DDEBT(-4) & FE & $R^{2}$ & No. obs. \\
\hline EU27 & $\begin{array}{l}0.677^{* * *} \\
(0.039)\end{array}$ & $\begin{array}{l}0.250 * * * \\
(0.065)\end{array}$ & $\begin{array}{c}0.033 \\
(0.026)\end{array}$ & $\begin{array}{l}-0.48 \\
{[1.03]}\end{array}$ & 0.642 & 804 \\
\hline EA12 & $\begin{array}{l}0.682^{* * *} \\
(0.053)\end{array}$ & $\begin{array}{l}0.380^{* * *} \\
(0.100)\end{array}$ & $\begin{array}{c}0.018 \\
(0.026)\end{array}$ & $\begin{array}{l}-1.29 \\
{[0.97]}\end{array}$ & 0.679 & 357 \\
\hline DSU3 & $\begin{array}{l}0.625^{* * *} \\
(0.072)\end{array}$ & $\begin{array}{l}0.557 * * * \\
(0.151)\end{array}$ & $\begin{array}{l}-0.051 \\
(0.033)\end{array}$ & $\begin{array}{l}-1.15 \\
{[1.90]}\end{array}$ & 0.843 & 90 \\
\hline CEE10 & $\begin{array}{l}0.568 * * * \\
(0.078)\end{array}$ & $\begin{array}{l}0.087 \\
(0.079) \\
\end{array}$ & $\begin{array}{c}0.029 \\
(0.041) \\
\end{array}$ & $\begin{array}{c}0.53 \\
{[0.95]}\end{array}$ & 0.597 & 300 \\
\hline EAnon7 & $\begin{array}{l}0.682^{* * *} \\
(0.073)\end{array}$ & $\begin{array}{l}0.409 * * * \\
(0.105)\end{array}$ & $\begin{array}{c}0.011 \\
(0.033)\end{array}$ & $\begin{array}{l}-1.06 \\
{[0.47]}\end{array}$ & 0.704 & 210 \\
\hline EAcris5 & $\begin{array}{l}0.662^{* * *} \\
(0.069)\end{array}$ & $\begin{array}{l}0.326 * \\
(0.188)\end{array}$ & $\begin{array}{c}0.026 \\
(0.036)\end{array}$ & $\begin{array}{l}-1.67 \\
{[1.28]}\end{array}$ & 0.609 & 147 \\
\hline CEEnon7 & $\begin{array}{l}0.625^{* * *} \\
(0.100)\end{array}$ & $\begin{array}{l}0.223^{* * *} \\
(0.082)\end{array}$ & $\begin{array}{c}0.016 \\
(0.044)\end{array}$ & $\begin{array}{l}-0.50 \\
{[0.64]}\end{array}$ & 0.638 & 210 \\
\hline CEEcris3 & $\begin{array}{l}0.479 * * * \\
(0.114)\end{array}$ & $\begin{array}{l}-0.157 \\
(0.166)\end{array}$ & $\begin{array}{l}0.194^{* * *} \\
(0.068)\end{array}$ & $\begin{array}{c}6.80 \\
{[6.05]}\end{array}$ & 0.568 & 90 \\
\hline
\end{tabular}

Notes: The dependent variable is the primary budget balance, PRIM. Instrumental variable estimation with country fixed effects and quarterly dummies. The variable G4Y is instrumented using the following instruments: GY(-1), GY(-2), GY(-3), and G4YEU. Robust standard errors are shown in round brackets. Superscripts ***, **, * denote that the coefficient estimate is statistically different from 0 at the 1,5 and 10 percent level of significance, respectively. The column FE shows the average and, in square brackets, the standard deviation of the country fixed effects. Quarterly dummies are included but not reported. 